\title{
The Effect of the Lumbar Pedicle and Pediculocorporal Junction Histology on the Pedicle Screw Insertion Technique
}

\author{
Murat Yilmaz*, Beyza Alkis, Kemal Yucesoy \\ School of Medicine, University of Dokuz Eylul, Balcova, Izmir, Turkey
}

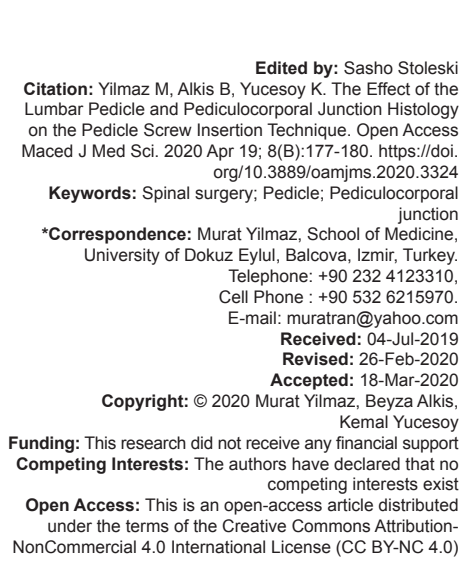

Introduction

Posterior lumbar pedicle screw instrumentation has gained wide acceptance in the treatment of various spinal lesions requiring fusion [1]. Inserting screws into the pedicles take a great deal of skill, as the dense bony parts are not large, and failure may push a bone fragment into the spinal nerves, causing pain, loss of mobility, and other neural damages. Pilot hole preparation and tapping are frequently used to prepare the tunnel for the pedicle screws; however, these maneuvers may lead to the perforation of the pedicle or corpus walls [2]. Self-tapping various cylindrical screws are currently in the clinical use to eliminate the need for tapping with a tunneler [3].

There are different fixation systems, surgical instruments, and insertion techniques, which have been developed for the safe insertion of the pedicle screws [1]. One of the main issues regarding the pedicle screw enforcement should be the histological properties of the pedicles, and especially the pediculocorporal junction, which has not been studied before. Any osseous web formation or histological change at this junction may influence the technique for the screw insertion [4]. Any osseous web formation or histological change at this junction may influence the technique for the screw insertion [4], [5].

The aim of the present study was to investigate the histological and gross-anatomical properties of the pediculocorporal junction, which can have important clinical implications on the insertion technique of the pedicle screws.

\section{Materials and Methods}

\section{Study design}

This study was approved by the University Clinical Center Review Board. Human cadaveric lumbar spinal segments that were fixed with formaldehyde were used in the study.

Twenty specimens, including a part of the corpus, pediculocorporal junction, and some parts of the pedicle, were prepared for the examination with the light microscope. About $10 \%$ of $\mathrm{HNO}_{3}$ compound were prepared in $70 \%$ ethyl alcohol and used for the decalcification process. Decalcification procedure lasted for 2 days, and then, specimens were embedded 
in paraffin blocks. Each paraffin block was sectioned with 5-6 $\mu \mathrm{m}$ thickness and five sections were obtained for each specimen (100 sections were obtained from 20 specimens). Specimens were stained with hematoxylin \& eosin and examined with blinded histologists.

\section{Outcome parameters}

The parameters studied were the histological properties and densities of the osseous tissue in the anterior (corporal), pediculocorporal junction, and posterior (pedicle) parts of the specimens. The properties of the bone marrow were also examined in three different segments of the specimens. Preparations were examined with a light microscope (Olympus $\mathrm{BH}-2$ Tokyo, Japan) and images transferred to the computer using a highresolution camera (JVC TK-890-E, Japan) and Aver TV Studio (Version 4.21.0.0, Aver Media Technologies, Inc.).

\section{Statistical analysis}

Data were analyzed using the Statistical Package for the Social Sciences 19.0 for Windows (SPSS Inc., Chicago, IL). Parametric tests were applied to data of normal distribution and non-parametric tests were applied to data of questionably normal distribution. All differences associated with a chance probability of 0.05 or less were considered statistically significant.

\section{Results}

Twenty human cadaveric lumbar spinal specimens were used in the study.

Gross-macroscopic examination of the specimens revealed that the trabecular formation of the spongious bone was dense in the posterior part and getting to some extent weaker and scarcer in the anterior (corporal) part (Figure 1). There was not any lamina or zone throughout the specimens starting from the corpus to the end of the pedicle. Bone marrow and adipose tissues of the osseous trabecula were the same in all parts of the specimens.

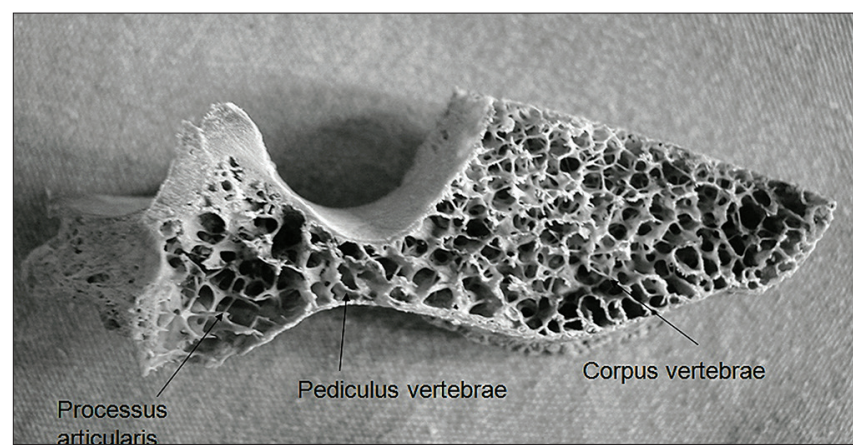

Figure 1: Gross-macroscopic examination of the specimen
The light microscopic examination revealed no differences in terms of the properties of the osseous tissue in the sequential slices of all specimens (Figure 2). There were also no histological differences among specimens obtained from the different spinal segments.

\section{Discussion}

The pedicle constitutes a relatively small part of the vertebral mass; however, it is clinically one of the most crucial elements of the spine [6]. The pedicle, a tubular bone, contains a spongy matrix surrounded by a cortical shell, participates in the formation of anterior and posterior vertebral columns from the corpus to the facets and it acts as a bridge that transmits the load on the spine to adjacent levels [7]. This unique anatomy of the pedicles provides an excellent implantation site for reconstructive spinal surgeries.

Lowe et al. hold that anterior column integrity is significantly involved in spinal reconstruction [8]. Implant subsidence is not only related to the biomechanical properties of vertebral endplates but also to the implant morphology, structure, and whether the endplate is preserved in operation. Hou and Luo stated that the central region with more and larger pore structures is weaker than the peripheral region of the lumbar endplate, and the strongest site is the posterolateral region in front of the pedicles [9]. Keller et al. tested $1 \mathrm{~cm}$ cubes of trabecular bone taken from the superior and inferior surfaces of lumbar vertebrae and found that there was regional variation in the strength and stiffness, which changed with disk de generation [10]. In his classic study on the vertebral endplate, Perey conducted indentation tests with a relatively large, flat indenter. He demonstrated that the strength decreases with age.

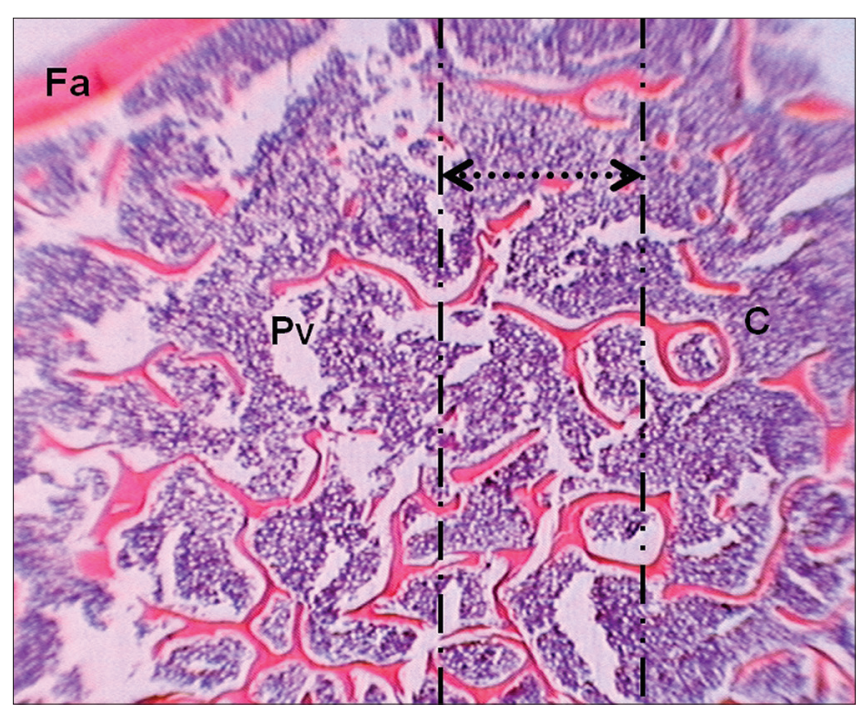

Figure 2: Pediculus vertebrae and corpus vertebrae (C) junction. Two-headed arrow showing the transition zone. Fa=Facies articularis (hematoxylin and eosin stain) 
He also concluded that there were no differences in the strength between the central, lateral, and anterior regions of the endplate, although he did not present the data [11]. The main concern in drilling a tunnel before the insertion of a pedicle screw is to prepare a passage passing through any compact lamellar osseous zones of the pedicle or pediculocorporal junction [12]. According to the findings of the present study, it can be a possibility to omit this step during surgery as the whole macroscopic, and histological architecture of the bone was found to be similar throughout the passage of the pedicle screw [13].

It is a common clinical finding that most of the pedicle fractures related to pedicle screws occur at the lateral wall of the pedicle [14]. In an in vitro study, Panjabi et al. inserted screws of different diameters into thoracic and lumbar pedicles [15]. With increasing screw diameter, they found changes in the pedicle structure (i.e., pedicle expansion, pedicle fracture, or cutout of the screw thread). Although there were as many lateral cutouts as there was medial, indicating that the entrance points for the screws were in the center of the pedicle, they saw $72 \%$ of pedicle fractures laterally and only $28 \%$ medially. The idea of cutting the pedicle to investigate its internal structure is not new. Foster cut the pedicle into $1 \mathrm{~mm}$ thin slices and obtained measurements of the cancellous and cortical dimensions along with the pedicle height and width [16]. However, they studied only two human specimens. They showed that the cortical shell thicknesses were between $10 \%$ and $30 \%$ of the pedicle height and between $15 \%$ and $40 \%$ of the pedicle width.

The main limitation of the present study was the relatively small size of our series. Second, some details of the history of the cadavers that may influence the results may not be completely documented. Due to these restrictions, associations should be interpreted with caution.

\section{Conclusions}

As the histological characteristics of the pedicle, pediculocorporal junction, and corpus are alike, the use of a tunneler during the spinal fusion operations can be omitted. All kinds of pedicle screws, including self-tapping ones, can be attempted to be inserted just after preparation of the insertion point with an awl or just decortication of the entrance point with a rongeur. This can also reduce the long awl and tunneler-related complications like perforation of the pedicle walls. Further randomized, prospective, and controlled trials on larger series are necessary for making more precise interpretations.

\section{References}

1. Lei W, Wu Z. Biomechanical evaluation of an expansive pedicle screw in calf vertebrae. Eur Spine J. 2006;15(3):321-6. https:// doi.org/10.1007/s00586-004-0867-1

PMid:15864667

2. Misenhimer GR, Peek RD, Wiltse LL, Rothman SL, Widell EH. Anatomic analysis of pedicle cortical and cancellous diameter as related to screw size. Spine. (Phila Pa 1976). 1989;14(4):36772. https://doi.org/10.1097/00007632-198904000-00004 PMid:2718038

3. Oktenoglu BT, Ferrara LA, Andalkar N, Ozer AF, Sarioglu AC, Benzel EC. Effects of hole preparation on screw pullout resistance and insertional torque: A biomechanical study. J Neurosurg. 2001;94 Suppl 1:91-6. https://doi.org/10.3171/ spi.2001.94.1.0091

PMid:11147874

4. Lill CA, Schneider E, Goldhahn J, Haslemann A, Zeifang F. Mechanical performance of cylindrical and dual core pedicle screws in calf and human vertebrae. Arch Orthop Trauma Surg. 2006;126(10):686-94. https://doi.org/10.1007/ s00402-006-0186-6

PMid: 16865403

5. Kothe R, O'Holleran JD, Liu W, Panjabi MM. Internal architecture of the thoracic pedicle. An anatomic study. Spine (Phila Pa 1976). 1996;21(3):264-70. https://doi. org/10.1097/00007632-199602010-00002

PMid:8742200

6. Sjöström L, Jacobsson O, Karlström G, Pech P, Rauschning W. CT analysis of pedicles and screw tracts after implant removal in thoracolumbar fractures. J Spinal Disord. 1993;6(3):225-31. https://doi.org/10.1097/00002517-199306030-00007 PMid:8347972

7. Yamaguchi K, Konishi H, Hara S, Motomura Y. Biocompatibility studies of titanium-based alloy pedicle screw and rod system: Histological aspects. Spine J. 2001;1(4):260-8. https://doi. org/10.1016/s1529-9430(01)00023-7

PMid: 14588330

8. Lowe TG, Hashim S, Wilson LA, O'Brien MF, Smith DA, Diekmann $\mathrm{MJ}$, et al. A biomechanical study of regional endplate strength and cage morphology as it relates to structural interbody support. Spine J. 2004;29(21):2389-94. https://doi. org/10.1097/01.brs.0000143623.18098.e5 PMid: 15507800

9. Hou Y, Luo Z. A study on the structural properties of the lumbar endplate: Histological structure, the effect of bone density, and spinal level. Spine (Phila Pa 1976). 2009;34(12):E427-33. https://doi.org/10.1097/brs.0b013e3181a2ea0a PMid:19454994

10. Keller TS, Hansson TH, Abram AC, Spengler DM. Panjabi MM Regional variations in the compressive properties of lumbar vertebral trabeculae. Effects of disc degeneration. Spine (Phila Pa 1976). 1989;14(9):1012-9. https://doi. org/10.1097/00007632-198909000-00016 PMid:2781407

11. Perey $O$. Fracture of the vertebral end-plate in the lumbar spine An experimental biomechanical investigation. Acta Orthop Scand. 1957;28(25):1-101. https://doi.org/10.3109/ort.1957.28. suppl-25.01

12. Inceoglu S, Burghardt A, Akbay A, Majumdar S, McLain RF Trabecular architecture of lumbar vertebral pedicle. Spine (Phila Pa 1976). 2005;30(13):1485-90. https://doi.org/10.1097/01. brs.0000168373.24644.9f

PMid:15990660 
13. Moran JM, Berg WS, Berry JL, Geiger JM, Steffee AD. Transpedicular screw fixation. J Orthop Res. 1989;7(1):107-14. https://doi.org/10.1002/jor.1100070115

PMid:2908900

14. Mummaneni PV, Haddock SM, Liebschner MA, Keaveny TM, Rosenberg WS. Biomechanical evaluation of a double-threaded pedicle screw in elderly vertebrae. J Spinal Disord Tech. 2002;15(1):64-8. https://doi. org/10.1097/00024720-200202000-00012
PMid:11891455

15. Panjabi MM, Shin EK, Chen NC, Wang JL. Internal morphology of human cervical pedicles. Spine (Phila Pa 1976). 2000;25(10):1197-205. https://doi. org/10.1097/00007632-200005150-00002 PMid:10806495

16. Foster MR. A functional classification of spinal instrumentation. Spine J. 2005;5(6):682-94.

PMid:16291111 